\title{
Critical Discourse Analysis of Vladimir Putin's Speech Related to Arm Race with the United States in 2018
}

\author{
Rani Herning Puspita ${ }^{1}$, Muhammad Dziqie Aulia Al Farauqy ${ }^{2}$, Sunarti Sunarti $^{1}$ \\ ${ }^{1}$ English Education Department, Universitas Muhammadiyah Kalimantan Timur, Samarinda, Indonesia \\ ${ }^{2}$ International Relationship Department, Universitas Muhammadiyah Kalimantan Timur, Samarinda, Indonesia
}

Email address:

rhp546@umkt.com (R. H. Puspita), mdaa343@umkt.ac.id (M. D. A. Al Farauqy),sun377@umkt.ac.id (S. Sunarti)

\section{To cite this article:}

Rani Herning Puspita, Muhammad Dziqie Aulia Al Farauqy, Sunarti Sunarti. Critical Discourse Analysis of Vladimir Putin's Speech Related to Arm Race with the United States in 2018. International Journal of Applied Linguistics and Translation. Vol. 5, No. 4, 2019, pp. 58-63. doi: $10.11648 /$ j.ijalt.20190504.12

Received: September 14, 2019; Accepted: October 22, 2019; Published: October 28, 2019

\begin{abstract}
The weapons war between Russia and America has been going on for a long time. The two countries are racing to make sophisticated weapons. This was always mentioned by Russian President in his speech, even when the main topic of the contents of the speech he delivered was far from gun battles. The purposes of this study are the researcher wants to find out the style of language Putin used in giving speeches and Putin's reasons for discussing America's unilateral resignation from the agreement on stopping the arms race, as well as what motivated Putin to announce Russia's missile superiority. The method used in this study was Teun Van Dijk's Critical Discourse Analysis method. From the research it was found that the way Putin made a speech he always greeted his listeners with the word "colleague" to build good relations with his listeners, and Putin's motivation to offend the American action was to announce that if a gun war occurs it is not Russia who started it but Russia will retaliate on the grounds defend themselves and it is considered a strategy in protecting the security of Russian people.
\end{abstract}

Keywords: Speech, Arm Race, Linguistics, Discourse Analysis

\section{Background}

The relationship between Russia and the United States is marked by an arms race (Arm Race) that never ends. Although there have been anti-ballistic weapons limitation efforts that are useful for national defense in the Strategic Arms Limitation Talks (SALT) 1 agreement in 1960 and SALT 2 in 1979, in fact, the two countries have even increased their military capabilities. The initial highlight was data reported by the "Memorandum of Understanding on the Establishment of the Data Base Relating to the Treaty between the United States of America and the Union of Soviet Socialist Republics on the Reduction and Limitation of Strategic Offensive Arms" which states that America and Russia (at that time the Soviet Union) had the same combat capability of more than 10,000 units, (US 10,564 , and Russia 10,271). This arms race is what we used to know with cold war that social and political impact has affected the whole world. In the aftermath of the Cold War, there was a fairly good progress in weapon limitation in the new plans in the Strategic Arms Reduction Treaty (START) 1 in 1991 and START 2 in 1993 which lasted until 2009, which prohibited possession of weapons above 6000 with conditions for maximum has 1600 intercontinental ballistic missile (ICBM) "intercontinental missile" missiles. However, it seems that the intentions of the two countries to reduce their military capabilities remain at the maximum threshold. Data reported by the "START Aggregate Numbers of Strategic Offensive Forces" in 2009, the US with 5916 units and Russia totaling 3897 to keep in mind, this number if combined constitutes $93 \%$ of the total world nuclear fleet. This is the scourge of the world. if Russia and the United States were in conflict, the world must be prepared in danger, not to mention the ballistic nuclear range that could reach the continent, a number of weapons would still threaten the security of the two countries.

The problem is, the matter of national security was being discussed again by Putin in his speech in March 2018 before the Russian Federal Assembly and the Duma legislature. Although the speech briefly contains only performance evaluation related to the achievements that have been 
achieved during Putin's leadership as President of Russia for two periods. In general, by looking at the contents of the speech, it is very clear that the purpose of the speech is to make the listener (Legislative) feel confident that Putin is the right President for Russia. The utterances in the speech must have the meaning and purpose of the speaker, whether the intent is spoken directly or indirectly. [15]. To understand the aims and objectives of the speaker (certain figures) can be studied through studies from pragmatics that is critical discourse analysis. In the analysis of critical discourse there are three things that can be analyzed, namely the maxro structure, micro structure, and superstructure, where all three can express the meaning behind the speech delivered. The purpose of this research is to find out the true purpose and function of the speech in a speech delivered by Russian President, Vladimir Putin. [14] Every speech, included political speech has a purpose to persuade others through arguments using in speech, that is why a speech must be in rhetorical way. According Aristotle, there are three kinds of rhetorical, also called Aristotelian Triad, they are ethos, pathos, and logos. Ethos means the character of the announcer or the speaker. Pathos is the role of audience or listener, and logos means the logic of the argument used in speech. [7] Based on the three rhetorical elements, the important thing of political speech is not the language used, but how to make the language is suitable to the context. [10] In case of Putin's political speech, when Putin gave a speech he also developed an opinion and invited the Russian public to elect him President of Russia for the third period. Putin's political speech was chosen as the object of research because instead of inviting listeners to re-elect him by showing achievements and work programs that will be implemented, such as state security, education, technology, and welfare of the Russian people, Putin, at the end of his speech, revealed other issues that according to him much more important than all the strategies that he will do that is related to the unilateral withdrawal of the United States and also about the accusations of the American state that Russia is designing missiles. Putin said that Russia always supports the world peace but in the same time he announced that Russian military has built hypersonic missile, and he said that Russia will always be ready if another countries launch their missiles. [3]

From the above study, this research was made. There is a need for more specific studies that can find out the motivation behind Vladimir Putin's speech, whether he only explains his strategies or is there another purpose. The research objectives to be answered in this study are (1) The reason of Putin is to emphasize that America does not keep agreements that have been agreed upon, and (2) Putin's motivation in his speech about the superiority of Russian missile technology.

Analysis in Donald Trump Presidential Campaign To Win American's Heart". There were four objectives of the research: 1) The utterances that illustrated political discourse in Donald Trump Speech; 2) The way he delivered his political discourse; 3) The aim of the utterances; 4) Effect of the utterance to people. The writer used descriptive qualitative as a method. The result of the research shown that Trump used several strategies to win the elections. Trump said that power is important to control many aspect in this world, and radical Islamic is to control the development of Moslem religion that is rising year by year in America. The conclusion of the research was that each utterance spoken by Trump represent the aims of his political speech. The aims were shown in the words of his speech.

The urgency of this research is the need for a new method approach in the study of international relations that can explain more comprehensively the various utterances, motives, and discourses of international actors which are intertwined into one in a speech text (Intertextualism). Likewise in linguistic studies, especially in Indonesia, there is still little application of the method of analysis in world political issues. This study stands between two branches of analysis, namely analysis of international relations as the background of the problem by using the Arm Race concept from Jarvis to explain the relationship between Russia and the United States (US) as a research boundary. [10]

\section{Literary Review}

\subsection{Arm Race in Global Politics}

The arms race that takes place in developed countries is common but also creates its own unrest. Countries that are competing to create weapons with sophisticated technology create mutual fear between nation-states because of a misunderstanding of other countries. With this condition of mutual suspicion, the dimension of state security is a top priority so that each nation-state will try to achieve and strengthen security by increasing its military expenditure. Because of that, there was an arms race between countries. Thus, in this condition each country is trapped in a dilemma, which is then referred to as the security dilemma in the form of an arms race. In the arms race there are conditions that enable it to continue to carry out an arms race. According to K. R Adams, there are three forms of state motives for arms races: first, Offensive operation, second, Defensive operation, and third, Detterence operation. [9]

Offensive operation can be interpreted as an action in which a country uses its military power to attack another country's military or non-military assets to conquer its territory or comply with directives compliance. While defensive operations are programs and capabilities designed to repel or prevent enemy attacks by controlling their territory to avoid having other countries impose their will on their country. The third is deterrence operation, which is an action in which the state prepares to use its military power only as an instrument to show its military capabilities to prevent the country from attacking or prevent it from other attacks if it is in conditions when the war has broken out. The function of deterrence is to keep the opponent from doing anything with the threat of punishment or by having the ability known to the opponent will hinder or frustrate any 
efforts such as damage in the event of war. [10] The concept of deterrence is to stop the opponent from using his first force, not to thwart an attack after the attack occurred. The principle is, an international relations actor can prevent other actors by increasing the actors' fear of the consequences that will occur. [12]

\subsection{Critical Discourse Analysis (CDA)}

Critical discourse analysis is one of the methods used in examining a text delivered by people who are interested and have the power where the text is delivered with a view to influencing the listener. There are several paradigms in Critical Discourse Analysis, namely:

\section{Positivist paradigm}

Positivists believe that looking at discourse without relating it to a specific context or the explicit intention of the utterance delivered, but seeing whether the discourse delivered meets the syntactic and semantic rules. In this case the discourse analysis is only to examine whether or not the discourse is in accordance with syntax and semantics.

2. Constructivist Paradigms

In the constructivist view, a discourse is not only to be understood objectively but speakers have control over the purpose or purpose of the discourse being taught. In this view, discourse analysis is intended to expose the hidden intentions of the discourse spoken by the speaker.

3. Critical Paradigm

This view assumes that the speaker is not a neutral individual who can freely express his thoughts through the discourse being taught but is influenced by the social forces that exist in society. Discourse analysis in this view is used to examine the power that exists in each language, the limits that are allowed to be spoken, the topic of the discourse being taught, and what perspective should be used. [4]

\subsection{Teun Van Dijk's Theory}

According to Van Dijk, analyzing a discourse is not only based on text, we also need to pay attention to how a text can be produced. [13] Van Dijk said that discourse has three dimensions, namely text, social cognition, and social context. At the level of the text being analyzed is the structure that builds the text and the strategies used to express the intended theme. Social cognition studies texts that involve individuals. The social context studies the structure of discourse that develops in society.

\subsubsection{Text}

Van Dijk divides the text into three levels. First, the macro structure: the global or general meaning of a text that can be observed by looking at the topic or theme put forward in a news. Second, the superstructure is the structure of discourse related to the framework of a text, how the parts of the text are arranged into the whole news. Third, the micro structure, is a discourse that can be observed from a small part of a text that is words, sentences, propositions, clauses, and images.

\subsubsection{Social Analysis}

Social cognition is a dimension to explain how a text is produced by an individual / group of text makers. How to see or see a social reality that gave birth to certain texts. Social analysis looks at how the text is further linked to the social structure and knowledge that develops in society over a discourse. These three dimensions are an integral part and are carried out together in van Dijk's analysis.

\section{Methodology}

\subsection{Data Source}

The data sources in this study were all the speeches in Vladimir Putin's speech in March 2018. The data analyzed were those that showed motivation.

\subsection{Research Design}

To examine the data, this study uses discourse analysis. Discourse analysis is a qualitative method that functions to analyze data in the form of text, speech, conversations both verbal and non-verbal. Through the discourse analysis method, researchers can discover why and how a message is conveyed. In addition, discourse analysis allows us to see what the purpose of the speaker in delivering speech. Discourse analysis also makes it possible to see motivations hidden behind a text. The focus of discourse analysis is all sentences in both written and oral form, and the ways or strategies of people in delivering their speech such as slowness, emphasis on words, metaphors, or choice of certain words. In discourse analysis, it is not only the problem of language that is discussed but also social problems and political knowledge. Discourse analysis can be applied in every situation and every subject.

According to Fairclough and Wodak (in Carrerron Jr. \& Svetanant., 2017) there are several characteristics of discourse analysis, namely 1). Action. Discourse can be understood as actions (actions) that is associating discourse as a form of interaction. Someone speaks, writes, uses language to interact and relate to others. Discourse in this principle, is seen as something which aims to debate, influence, persuade, support, react and so on. Besides the discourse is understood as something that is expressed consciously, controlled is not something out of control or expressed consciously. 2). Context. Discourse analysis considers the context of the discourse such as settings, situations, events and conditions. The point of concern is the discourse analysis describing the text and context together in the communication process. 3). Historically, placing discourse in a particular social context and can not be understood without including the context. 4). Power.

The stages of this research were begun by reading the entire contents of Putin's speech, then the researchers analyzed the macro structure, micro structure, and superstructure of the contents of the discourse expressed by Putin. After reading the entire contents of the text, the next step is data reduction, where only the necessary data is 
examined and unnecessary data will be discarded. The selected data is data that will answer the questions from the study. After that the researcher will analyze the true intentions of the entire contents of the speech texts and sentences that show the true intentions of the speech viewed in terms of pragmatics and use discourse analysis. After that the final stage, namely drawing conclusions that are answers to the problems studied.

The data will be analyzed using Van Dijk's theory, which means that the speech will be analyzed by macro structural analysis, super structural analysis, and micro structural analysis. Macro analysis is finding the global theme of the discourse or text to be studied. In micro analysis, researcher will analyze words, sentence, or picture, while superstructure analysis will analyze how a text is built, such as opening, closing and conclusion.

\section{Findings and Discussion}

\subsection{Macrostructure Analysis}

The theme of the speech delivered by Russian President, Vladimir Putin is the national development and domestic economy as expected by the Russian people. Putin conveyed this theme at the beginning of his speech. Putin said:

"Today's Address is primarily devoted to matters of domestic social and economic development. I would like to focus on the objectives set forth in the May 2018 Executive Order and detailed in the national projects. Their content and the targets they set are a reflection of the demands and expectations of Russia's citizens. People are at the core of the national projects, which are designed to bring about a new quality of life for all generations. This can only be achieved by generating momentum in Russia's development."

Putin's speech above is an opening in his speech by conveying a theme or topic that will be discussed and delivered in his speech. In the above statement also Putin stressed that the targets they set were in accordance with the demands and expectations of the community. Here Putin wants to emphasize that Putin as much as possible to make the demands and expectations of Russian people come true by saying:

"Their content and the targets they set are a reflection of the demands and expectations of Russia's citizens. People are at the core of the national projects, which are designed to bring about a new quality of life for all generations."

The sentences emphasizes the main things that will be discussed by President Putin in his speech which is contained of strategies and policies that will be taken by the government to make all the demands and expectations of the Russian people during his leadership such as health, education, infrastructure, welfare and others come true.

\subsection{Superstructure Analysis}

Superstructure analysis will analyze the opening of the speech, the contents of the speech, the closing and conclusions of the entire contents of the speech. In this speech there are some information about the strategies that Putin used to improve the life quality of Russian society. In each part of strategy there are introductory, content and closing sentences. Before starting to discuss the program to be carried out, Putin began his speech with the sentence:

"Colleagues, Let me now share some specifics on our objectives".

The opening sentence above is enough to get the listener's attention in case to pay more attention to what Putin will say next. This opening sentence is very important to be used as an opening so that the attention of the listener is focused on us.

Next to the sentence content of the speech, Putin also uses the opening sentence to begin the translation of its programs. Topics covered include:

\subsubsection{Support for Family Welfare}

The phrase "Family, childbirth, procreation and respect for the elderly have always served as a powerful moral framework for Russia and its multi-ethnic people", opened the topic of the family. The sentence shows Putin respected family values and the well-being of families and seniors. That is proven in utterances:

"Russia has entered an extremely challenging period in terms of demographics. As you know, the birth rate is declining. As I have already said, this is caused by purely objective reasons, which have to do with the immense human losses and birth dearth experienced by our country in the $20^{\text {th }}$ century, during the Great Patriotic War and the dramatic years following the dissolution of the Soviet Union. This does not mean, however, that we must accept this situation or come to terms with it. Definitely, not. We succeeded in overcoming the negative demographic trends in the early 2000s, when our country faced extreme challenges. This seemed to be an impossible challenge at the time. Nevertheless, we succeeded, and I strongly believe that we can do it again by returning to natural population growth by late 2023 - early 2024."

The sentences above are used by Putin to show his concern about the declining birth rate in Russia caused by certain things, but Putin also believes that the birth rate will return to normal by carrying out some strategies shown in the sentence:

Today, I want to talk about a new package of measures that has already been prepared to support families."

The closing sentence became Putin's assertion that he really would carry out all the strategies that he uttered.

"I would like to emphasize that the package of measures to support families proposed today is not an exhaustive list of initiatives. It sets the priorities."

\subsubsection{Poverty}

To begin the discussion of the second problem, poverty, Putin used sentences:

Colleagues, solving our demographic problems, increasing life expectancy and reducing mortality rates are directly related to eradicating poverty." 
The opening sentence used by Putin shows the way or strategy he will use to alleviate poverty, the sentence also emphasized that Putin really concern about the problem:

"There are many reasons for poverty, not only in our country, but also in the world, but it always literally crushes a person, dimming their life prospects. The state must help people, help them out of difficult life situations ," then the sentence content continues with." The state helps people find jobs and improve their skills. The state provides financial resources to families to run a household farm or to start a small business, and by the way, these are substantial resources of tens of thousands of rubles. Let me emphasize...."

In the speech section, Putin explained more detail about the strategies he will use to reduce poverty. By explaining in detail the strategies he will undertake, it is hoped that the Russian people will trust him and elect him again as a President of Russia. To reassure the Russian people, Putin showed his seriousness in helping people find work and improve community capacity.

Putin summarizes the entire program as the closing speech of the session that discusses the problem of poverty.

"I would like to emphasize that all those who work in the social sphere or join the government or municipal services in order to help people solve their urgent problems, must meet the highest professional standards."

To be more convincing, Putin emphasized that he would ask social employees and employees at high standard government offices to help the government solve poverty problems.

\subsubsection{Health Problems}

The next issue that Vladimir Putin will address in his speech is health, both public health and environmental health.

"Colleagues, The next important subject is healthcare. I know that, on the one hand, its current state seems to be improving, and medical treatment is becoming more accessible".

To open the next discussion, Putin directly refers to the matter that will be discussed, namely health. Emphasis on the importance of government attention on health issues is shown in the sentence above.

\subsubsection{Infrastructure and Transportation}

"In September, we will have a meeting in Vladivostok to discuss what each of the federal agencies has done and intends to undertake for the Far East. All the plans for building and upgrading roads, railways, sea ports, air services and communications must prioritize regional development, including promoting these regions as travel destinations. There are enormous interests in Russia, our culture, nature and historical monuments. Taking into consideration the success of the World Cup, I propose making greater use of e-visas and thinking more broadly about how to streamline visa processing for tourists coming to Russia. Next, this year we must adopt a master plan for developing the infrastructure of a digital economy, including. telecommunications networks, as well as data storage and processing capacities."

In the sentence "In September....." Putin said what he had done strategy to improve the infrastructure. The utterances above said to convince the public that the Russian Government is serious about improving infrastructure and transportation facilities such as railroads, roads, water transportation, and other transportation.

From the discussion above we know that the content of the speech is explanation about the strategies that will be taken by the Russian Government because it is described in the beginning of speech and also uttered in the speech. At the opening of the speech Putin will discuss the hopes and demands of the Russian people and the entire strategies above are the Russian government's answer in this case is President Vladimir Putin, about the hopes and demands of the Russian people, but in the end of the speech Putin alluded to American actions that were not correlated with the hopes of the Russian people. Putin considered it is important to discuss the withdrawal of the American state from the INF Treaty, because it was considered a violation of the agreement to stop the production of missile weapons, this was revealed in the sentence:

"I am talking about this and using my time and yours because we have to respond to the accusations that are leveled at us. But having done everything I have just described, the Americans openly and blatantly ignored the provisions envisaged by articles 4 and 6 of the INF Treaty."

Putin said that other countries could not blame or accuse that Russia was still producing missile because Russia supported peace by continuing to abide by agreements that Russia had signed. Stated in the sentence:

"I am saying this directly and openly now, so that no one can blame us later, so that it will be clear to everyone in advance what is being said here. Russia will be forced to create and deploy weapons that can be used not only in areas that are directly threatened from, but also in areas that contain decision-making centers for the missile systems threatening us."

The above statement confirms that Russia has always complied with agreements on missile weapons and has never placed missiles on certain countries, but on the other hand Putin also stressed that Russia's position is to survive by creating hypersonic missiles that can be launched on or on the surface of water. It indicates that Russia is always ready in facing any attack but Putin emphasized that Russia launched the missile if only they been attacked by other country. In other words, Russia warns the the America (US) that Russia will only react if the US tests a missile. From the various utterances discussed above it can be concluded that according to Putin, in addition to the problem of the welfare of the people, the safety of the people has become one of the concerns of the government, besides Russia also wants not to be considered as a country that started the weapons of destruction but Russia is only in a position to defend itself. It is prove that the relationship between Russia and US can hardly friendly. 


\subsection{Micro Structure Analysis}

President Putin used the word "colleague" at the beginning of each discussion of a topic is deliberately carried out so that the distance between the people and their leaders is getting closer. The word "colleague", which when interpreted semantically is a person of the same position, is used by Putin to show the people that their position is equal. In addition to the word colleague used at the beginning of each topic, Putin also almost always uses the word "emphasize" to end the topic of discussion. This shows Putin earnestly in every that he uttered or if in a pragmatic point of view becomes a commissive sentence where the speaker will do what he says.

\section{Conclusion}

From the discussion above we get several results from each analysis. Based on a macro-structural analysis at the beginning of his speech Putin briefly explained the contents or topics to be discussed in sentences that made his listeners pay more attention to what was to be delivered. From the analysis of the superstructure, in terms of the content of the speech, Putin explained in detail by describing the details of the strategy, before describing the details of Putin's strategy beginning with a brief explanation of what the government had done, then in the closing section Putin used an emphasis sentence to show his seriousness to meet everything the hopes of the Russian people. From the micro structural analysis it was found that Putin wanted the people to feel that the position between the President and the people was the same, so Putin always used the word "colleague" and to make people confident that Putin would do what he said, the word "emphasize" was used almost at the end of each topic. Putin's motivation for offending the American action is to announce that if a gun war occurs it is not Russia who started it but Russia will retaliate on the grounds of self-defense.

\section{References}

[1] Adams, K. R. (2004). Attack and Conquer? International Anarchy and the Offense-Defense-Deterrence Balance. International Security.
[2] Bulan Arif, Kasman. 2018. Critical Discourse Analysis of Ahok's Speech in Kepulauan Seribu. Jurnal Bahasa, Sastra dan Pengajarannya.

[3] Carreron, J. R. \& Svetanant, C. (2017). What Lies What Lies Underneath a Political Speech? Critical Discourse Analysis of Thai PM's Political Speeches Aired on the TV Program Returning Happiness to the People. Open Linguistics. 3 (1). Hal: 638-655.

[4] Hashim, S. S. M. (2015). Speech Act in Selected Political Speeches. International Journal of Humanities and Cultural Studies. 2 (3). Hal: 396-406.

[5] Leech, G. (1983) Principle of Pragmatics. Terjemahan ke dalam Bahasa Indonesia dilakukan oleh M. D. D. Oka. 1993. Prinsip-prinsip Pragmatik. Jakarta: UI Press: London: Longman.

[6] Murthy, D. Madhavi Latha. 2014. A Study on Aristotle's Rhetoric. Research Journal of English Language and Literature (RJELAL) Vol. 2. Issue. 4. KY Publications.

[7] Piver. S (2017). The Future of U.S.-Russia Nuclear Arms Control. Conference proceedings of American Institute of Physics. https://doi.org/10.1063/1.5009206.

[8] P. R. Vioti \& M. V. Kauppi. 2013. International Relations and World Politics. New Jersey: Pearson.

[9] Rahman Andhita, Sofi Yunianti. 2017. Critical Discourse Analysis In Donald Trump Presidential Campaign To Win American's. Surabaya: Universitas Muhammadiyah Surabaya.

[10] Selden, Raman, and Peter Widdowson. 1993. A Reader's Guide to Contemporary Literary Theory: Third Edition. Kentucky: The University Press of Kentucky.

[11] Sulistyo, Iwan. 2017. Dinamika Persenjataan di Asia Tenggara, 2010-2015 (Weapons Dynamics in Southeast Asia, 2010-2015). Padang: Andalas Institute of International Studies.

[12] Van Dijk, Teun A. 2001. Critical Discourse Analysis, Book 1. Bandung: Universitas Pendidikan Indonesia.

[13] Virginia, O. C. \& Olanrewaju, A. T. (2017). A Speech Act Analysis of Hate Speeches in 2015 General Election Campaign in Nigeria. IMPACT: International Journal of Research in Humanities, Arts and Literature (IMPACT: IJRHAL). 5 (6), Hal: 61-72.

[14] Yule, George. 1996. Pragmatics. England: Oxford University Press. 